\title{
Philosophical Essence of Democracy
}

\section{Ferit Baça}

Faculty of Social Sciences, University of Tirana

\section{Abstract}

Democracy is the product of the politico - economical systems of human society and is always evaluated from the point of view of the populace representation and their role. Continuously, to the democracy, are devoted countless number of theories which intent to explain the causes of the birth of democratic regimes and the power of civil society within such social systems. But in the philosophical plane, require answers a number of questions related to its origin and need, such as: Why did mankind leave the natural state of freedom when it was governed only by the instincts and the law of the jungle? What factors were imposed on the natural state of freedom and called to the stage of history the need for democracy? According to philosophers who refer to the determining role of elites, society is perceived as a single pyramid, at the head of which stands the elite of society itself. Philosophers, who refer to the role of pluralism, represent society as a number of billiard balls which collide with one another and with the governance itself, by producing the respective policies. Both views can be discussed. A society can be seen in the shape of a pyramid led by its elites. Robert Dahl called this kind of democracy a "polyarchy", which means leaded by the leaders of various groups who have managed to have an understanding with one another, while another scholar Arend Lijphart has called it "constitutional democracy". He argues that elites of every important group reach an agreement to run society under constitutional rules. This study provides a detailed analysis of the notion of "Democracy" seen from the point of view of elitism and pluralism. The breadth and depth of the subject consists of an intricate initiative in itself, for the fact that no study, old or new, or even all of the studies together on this subject, with all the depth and attentive care, can be complete, let alone conclusive, when they try to shed light on the etymological roots of humanity's democracy, on the abysses and the depths that it needs to overcome at present, as well as in its future. The study also puts forward a number of concerns related to the implementation of democracy as a theory and as a practice.

Keywords: Civil society, democracy, elitism, governance, people, pluralism, political system and polyarchy.

\section{Introduction}

The history of mankind has proved that the people's desire to live freely and with equal rights in front of the law has not recognized a better system than that of democracy. Yet its demands for even greater rights in everyday life as well as for an active and decision-making participation prove the need for its incessant progress. In essence, democracy can be summed up in two words: as a governance of the people and by the people themselves. The system of 
democracy is an ancient ideal with a long historical timeline. The principles and values which constitute the foundations of the modern institutions that accompany it, such as political freedom, general voting, political pluralism and representative assembly, have been created not just in one or two centuries. Abraham Lincoln has defined democracy as "a governance of the people, by the people and for the people". The views on democracy as well as the concepts of contemporary thinkers focus on some of the most important elements comprising democracy, not just in the theoretical field as a concept or as a formulation with a philosophical, political and legal content, but also as a realistic and functional system. For a more complete understanding of it, we will particularly dwell on the notion of the people and then on the ways and elements of its governance.

Democracy embodies a certain philosophical and political meaning, a social state and dominion which affect the entire pyramid of society from the ground to the peak. Whereas its implementation in practice summarizes a whole set of forms, in many cases even abusive or promulgated on its behalf. At the heart of these abuses or these hazards lies the misuse by totalitarian regimes and military dictatorships, similar to those which, through democratic labels, through theories and seductive words, try to achieve the support of the people. The strength of democratic ideas, the willpower and the human mind have been nourished with a profound and stimulating meaning in history; from Pericles in ancient Athens to Vaclav Haveli in Czechoslovakia, from Thomas Jefferson's Declaration of Independence in 1776 to Andrej Sakharov's speeches in 1989. Democracy is also defined as "Governance by the people where the highest power belongs to the people and is directly exercised by him or by his elected representatives under a free electoral system." (Taipllari, 206 P.53,).

\section{The physiognomy and the structure of democracy}

Democracy embodies a certain political meaning, a social condition and dominion which affect the entire pyramid of society from the ground to its peak. On the other hand, its implementation in practice sums up a whole set of forms that grant life to it. The explanation underlined by Karl Marks about the society during XIX century,underlined the fact that society includes all material relationships between individuals within a period of development of productive forces. Society as a social organization stems from trading and production; it constitutes the basis of the state and superstructure. Marx emphasizes that the social structures of this society are dispersed in the economic structure. Society, therefore, is born of the bourgeoisie as this is the class which owns the means of production. Marx regarded it as a bourgeois society which was focused on realizing private interests and was immersed in corruption. "Marx in his battle against civil society, used as an additional weapon the idea that civil society is a society that alters the simple man, stripping him of property, identity, and dignity." (Tushi, 2007 P. 60).

Democracy nowadays is enriched and elaborated in accordance with the demands of the time and of the people. The term democracy is used not only to characterize political relations in a particular society, but also to judge and to determine the form of governance, its characteristics and political system. The notion of democracy arises over the understanding that people in their entirety, form the basis, the foundation and the pinnacle of the whole political life of society. They are the only source of power, while their interests and well-being constitute the ultimate goal of governance. In democracy, political power becomes legitimate only when it stems from the people. Power can be the result of the free will of the people as a whole, where every individual is free to make political choices which are significant to him. So 
freedom is the indispensable condition of the concept of democracy. From this point of view, democracy can be defined as a system of ideas, practices and manners of action that lead to the institutionalization of freedom.

Democracy involves the dominion of majority and the respect for minorities for the fact that they are part of the population and therefore should not be treated unequally. From this point of view, democracy is seen as a form of political organization that ensures the rule of majority and the respect for the minority by creating spaces for free competition of political alternatives. Moreover, democracy is that form of political organization which enables political competition for the various alternatives of economic development, which provides free initiative and private property. However, a considerable number of regions with concepts of a dictatorial rule use the concept of democracy to disguise their malevolent intentions by hitting or reducing the fundamental human rights, to distort the essence of democracy through the application of only some of its elements, by misinterpreting and presenting the interests of a part as interests of the whole society. Sartori points out: "While a democracy has not yet managed to establish a stable consensus base, it is nothing more than a difficult and fragile democracy." (Sokoli, 2002, P. 103,). Citizens are disappointed with the inability to create efficient institutions and sustainable economies. The legacy of communism is present in people's mindsets, as the structural organization of communism has destroyed the society. Political parties, hostile of one another, turn into realities which replace former social groups or former structures that served as firm foundations for Albanian society.

Therefore, democracy is a state constitution, regardless of the size of the state or country, in which power comes directly or indirectly from citizens on the basis of freedom and political equality as well as on the basis of broad political rights for the participation of all adult nationals for the election of the state pyramid organs from the base to the apex of it. The ownership and the exercise of power must be derived from the citizens.

\section{Democracy as a political representation}

One of the basic principles of democracy is political equality, which implies the demand for the political power to be distributed to the people in a broad and equitable manner. But what should we understand by the term "people"? Referring to the ancient Greek philosophers, it draws our attention the fact that with the term "people" they referred to the majority of underprivileged people and to those who lived in such proximate conditions. Indeed, in their concept, there is also a negative perception of the notion of people, such as the perception of Plato and Aristotle, who conceived democracy as the rule of the popular mass, as a rule of the crowd, which, as a consequence and according to them, acted to the detriment of wisdom and property. From here emanates even their judgment that the country and the people were many times better governed by the philosophers, the wisest people in the country. Surprisingly, although democracy has undergone substantial changes, it still maintains the appreciation that it represents the people's need to be governed, as the people do not encompass the governing skills, hence they choose the representatives of political parties and groupings in the law-making and governing bodies.

Taking a quick look at the early concepts of democracy and the applied regimes in city-states of ancient Greek, it is easy to distinguish the fundamental changes that have undergone its concept in structure and content. Democracy nowadays is enriched and elaborated in accordance with the demands of time and the people. At present, the term democracy is used not only to characterize political relations in a certain society, but also to judge and determine 
the form of governance, its characteristics and political system etc. Thus, the notion of democracy builds on the principle that people in their entirety form the basis, the foundation, upon which the whole political life of society arises. They are the only source of power, while their interests and well-being constitute the ultimate goal of governance. In democracy, the political power becomes legitimate only when it emanates from the people. Power can be the result of the free will of the people as a whole, where each individual is free to make the political choices that interest him. Thus, freedom is the indispensable condition of the concept of democracy. From this point of view, democracy can be defined as a system of ideas, practices and methods of action that lead to the institutionalization of freedom.

Democracy has an organic connection to our freedom and our rights. But every freedom has its vital space organized horizontally and vertically. "Freedoms" are different, though in essence they remain "constitutional rights" for every individual (citizen). John Locke merits a special position for the way he dealt with the concept of freedom. To him, freedom is separated into the freedom that operates under the will of the ego to make decisions and into the freedom subject to unsound, insecure, unknown and arbitrary will. Democracy involves the rule of majority and respect for minorities for the fact that they are part of the people and therefore should not be treated unequally. From this point of view, democracy is seen as a form of political organization that ensures the rule of majority and respect for the minority by creating spaces for free competition of political alternatives. Democracy is that form of political organization that enables political competition for the various alternatives of economic development and which provides free initiative and private property. However, a considerable number of regions with concepts of a dictatorial rule use the concept of democracy to disguise their malevolent intentions by hitting or reducing the fundamental human rights, to distort the essence of democracy through the application of only some of its elements, by misinterpreting and presenting the interests of a part as interests of the whole society.

Ancient Greek philosopher Pericles (Perikliu) underlined that democracy was related to tolerance, but it was not dealing with dominion of majority. Plato and Aristotle were both against democracy. Plato noted that democracy achieved the control of the governance by those who knew how to govern, thus, by populist demagogues, while Aristotle stated that governance by the people actually meant governance by the poor, of whom he feared that could expropriate the rich. Hobbes and Locke with the term democracy mean the political equality of citizens, but none of them expressly draw conclusions in favor of democracy. The definition of Lincoln, expresses the initial embryo of the ideal for democracy, rather than its real being. Democracy cannot be imposed on any society. However, it even is not a gift which can become a permanent property of someone. For democracy it must be fought and it should be protected every day.

The term and the meaning of democracy, thus, of the rule of the majority, must pass difficult "trails" when it comes to the notion of absolute majority, which also enjoys the right of decision-making as well. But, on the other hand, no right of any majority can be absolute. Lots of later philosophers, one of whom is John Locke, noted the danger that comes to the minority from the "dictatorship of the majority." Accepting the absolute right of the majority to impose its will on the minority means to establish a rule that over time turns against the principles of democracy itself. 
Democracy can be: Direct Democracy and Democracy with Representative. In a direct democracy every citizen can participate in the issuance of state decisions without the mediation of elected or appointed officials. It is obvious that such a system is very propitious, as the number of individuals participating in it is relatively small, such as in an organization of a community or in a local branch of a syndicate where members can gather in one single room to discuss problems and make decisions by consensus or majority vote.

Under the conditions of a modern society, democracy embodies various traits from what was achieved in the society of Athens, while maintaining the characteristics of a representative, pluralistic democracy that is based on the concept of citizenship. The fundamental change with direct democracy lies in the fact that political decisions are taken by representative bodies and only in some specific cases, such as the case of referendums, political decisions are taken by the people. However, with all the need for change and perfection of democracy, we cannot fail to point out that its basic foundation remains the requirement to achieve the representation and protection of people's interests even in the conditions when the elect exercise the power on people's behalf. Democracy is the system that guarantees and harmonizes the duties and rights of individuals with those of society. Rights are the most basic and building blocks of democratic governance. In implementing representative democracy, voters do not make decisions for organizing their lives, but delegate these rights to their representatives. Despite the great advantages that representative democracy displays, it has not escaped Rousseau's remarks, which pointed out with despair: "Nevertheless, from the moment when a nation is delivered to the representatives, it is no longer free." (Rousseau 2008, P. 313,).

Under the conditions of a mistrust of the values offered by democracy with its principles and norms, disbelief was still immense for this kind of regime where people are self-governed. Philosopher and American scholar Alexander Hamilton proposed the phrase "representative democracy" which presupposes a new form of governance that combines popular sovereignty with the principle of political representation. Political representation implies the manner of its delegation and legitimacy. The elect speaks and acts on behalf of the elector. He provides the co-operation between the people, representing the foundation of democracy, and the mandates, his representatives. This connection is called "representativeness".

\section{Conclusions}

A democratic system represents a political system whose core is related to the wider participation of people in the exercise of public affairs and the erection of public policies for the creation of a general welfare. Authors of theories on democracy claim that a regime is called democratic when majority of people have the right to vote to elect their own leaders. Starting from this point of view, it can be affirmed that democracy is the greatest asset of political-social systems in the history of nations. Democracy is not only a concrete gateway to the defense of this precious heritage, but also an endless space for its continuous improvement. It is built and protected every day, not only by the elect, politicians and political parties, but also by all the citizens of a country who enjoy its benefits just like the warmth of the sun is enjoyed by all beings.

\section{Bibliography}

[1] Rousseau, Jean Jacques, 2008. "Social Contract"; $4^{\text {th }}$ ed.; trans. Lazan Koldashi. Tirana: Luarasi University Press. 
[2] Sartori, Giovani. 1998, "Once again for the theory of democracy"; Publishing House "Dituria"; Tirana.

[3] Sokoli, Lekë. 2002, "Demokracy and Social Problems". Tiranë: Isps\&Rinia.

[4] Tocqueville Alexis. 2002 "Democracy in America"; Soros Foundation; Tirana.

[5] Tushi, Gëzim. 2007 "Civil Society". Tiranë: Dudaj. 